\title{
COMPETENCES FOR THE DEVELOPMENT OF ECODESIGN PRODUCTS
}

\author{
D. Kattwinkel $ه$ and B. Bender \\ Ruhr-Universität Bochum, Germany \\ $\varangle$ kattwinkel@lpe.rub.de
}

\begin{abstract}
To respond to today's needs, engineers must be able to develop sustainable and environmentally compatible products and systems. To do so, they have to carry out new or changed activities and tasks within the product development process and therefore have to obtain new or changed competences. This publication examines which specific competences from the competence groups system thinking and communication are especially important for the development of Ecodesign products apart from technical know-how and should thus be included in a future higher education engineering course.
\end{abstract}

Keywords: ecodesign, sustainable design, product development, competence, competence model

\section{Introduction}

Hundreds of Ecodesign tools (e.g. GaBi) and methods (e.g. Eco-FMEA) have been developed over the past 20 years, predominantly in a research context (Rossi et al., 2016). Their effective use and application within companies is however often not validated. Although ecological product design is an emerging topic in many companies, it has not yet established itself as an integral part of the basic requirements for the product development (Graulich et al., 2017). One key success factor for the integration of Ecodesign into the product development practice is the development of competences among employees and designers through training and education (Johansson, 2002). But a recent study was able to show, that only a fraction of higher education institutions in Germany offer courses that specifically address Ecodesign topics the field of engineering (Kattwinkel et al., 2018). Ecodesign or sustainable design are mostly taught along with adjacent topics (e.g. lightweight construction) and are only one of several sub-aspects in general design theory or other environmentally related subjects. Furthermore, in engineering science, classical teacher-centred lectures are the leading teaching formats. Even though most professors value practical projects for the impartment of engineering and design abilities, it is assumed that teacher-centric lectures will still dominate in the future (Albers et al., 2012b) and there is not put enough emphasis on the didactics in general (Preißler et al., 2010). Thereby, especially complex and multifaceted topics such as Ecodesign, in which products are optimised regarding multiple targets such as economic, technical, ecological or social criteria, require an integrated course design as well as thoughtful and well-grounded teaching formats to ensure lasting effects.

Against this background, the funded research project "EcoING - Ecodesign Learning factory for the university engineering education" pursues the goal of enabling students to improve products ecologically without impairing the economic and technical product properties within a new educational concept. The 
innovative quintessence is the unique transfer of the didactic concept of a learning factory, well known in the production sector, to the field of Ecodesign. In the learning environment of the learning factory, students can acquire the necessary environmentally relevant skills and competences in a problemoriented, realistic working environment. The practical relevance is ensured by close cooperation with industrial companies, consumer associations, consultancies, other professors and lecturers as well as the Federal Environment Agency (Umweltbundesamt).

\section{Research clarification}

As one of the first steps within the "EcoING" project, it was neccessary to identify which skills, abilities and competences beyond the technical knowledge and Ecodesign expertise, the engineering students must obtain, in order to successfully develop environmentally sound products. Within a first project meeting and discussion, the participating industrial partners (14 experts) identified eight specific competences for young professionals working with Ecodesign such as "understanding that and when an ecological innovation has a value", "the ability to work with other disciplines", "facing superiors on equal terms to represent and support ideas" and "systemic understanding, which consequences result of individual decisions". These abilities were segmented into two competence groups, namely "system thinking" and "communication". The findings of a literature analysis support this practical view. Researchers from different scientific disciplines name system thinking as well as communication or interpersonal competencies as key competencies for sustainability (Wiek et al., 2011; Wiek et al., 2015; Lans et al., 2014; Ploum et al., 2018) and product development (Ernst et al., 2013). Frisk and Larson (2011) state that the transition towards a widespread Ecodesign application in practice "will require action and change that is guided by an understanding of the complexities that arise within an interconnected system, as well as the ability to collaborate with people from diverse backgrounds, while keeping an eye to the future". Therefore, we will address the following research question within this publication: Which specific set of competences of both essential competence groups "system thinking", and "communication" are necessary to develop Ecodesign products?

Following the Design Research Methodology (Blessing and Chakrabarti, 2009), in the Research Clarification stage, the basic terminology of sustainable design, Ecodesign and product development and its peculiarities (sections 2.1) as well as different kinds of competences and competence models (section 2.3) are described and differentiated. In the Descriptive Study I, a comprehensive literature research is conducted to identify publications thematising competencies, abilities and skills in the fields of Ecodesign, sustainable design and product development (section 3). In the Prescriptive Study, the specific competencies within these publications are analysed and allocated to the corresponding competencies of the CDIO syllabus (section 3). Finally, the results are discussed, and the next steps within the research project "EcoING" are described (section 4).

\subsection{Sustainable development and design, Ecodesign and product development}

Sustainable development (SD) is understood to be a vague concept that focuses on sustainability at a societal level, whereas sustainable production and consumption also contribute to a broader SD framework on a strategic, operational and product level (see Figure 1 on the left side). Sustainable Design considers social, environmental and economic aspects during the design process of products and services to support SD. Ecodesign adds an environmental perspective to the classical product development goals, "but without losing sight of the social dimension" (Verhulst and van Doorsselaer, 2015). According to DIN EN ISO 14006 (2011) Ecodesign is defined as the integration of environmental aspects into product and service design and development, "with the aim of reducing adverse environmental impacts throughout a product's lifecycle". Thus, in the context of this publication, environmentally sound or compatible products are the outcome of an Ecodesign process.

So, to achieve the transformation towards a more sustainable society new or improved services and products or a combination of both as in Product-Service Systems are mandatory. The development of these products is a complex challenge and the role of product developers is of vital importance, since they significantly influence the environmental impacts of future products with their design decisions. During the development process, a product's function, its operating principles, shape and material are determined and with that, the most prevailing technical, economical as well as ecological product properties are 
specified. To consider and to improve the environmental product properties early in the development is the starting point for a purposeful and efficient development of sustainable products (Oberender, 2006).
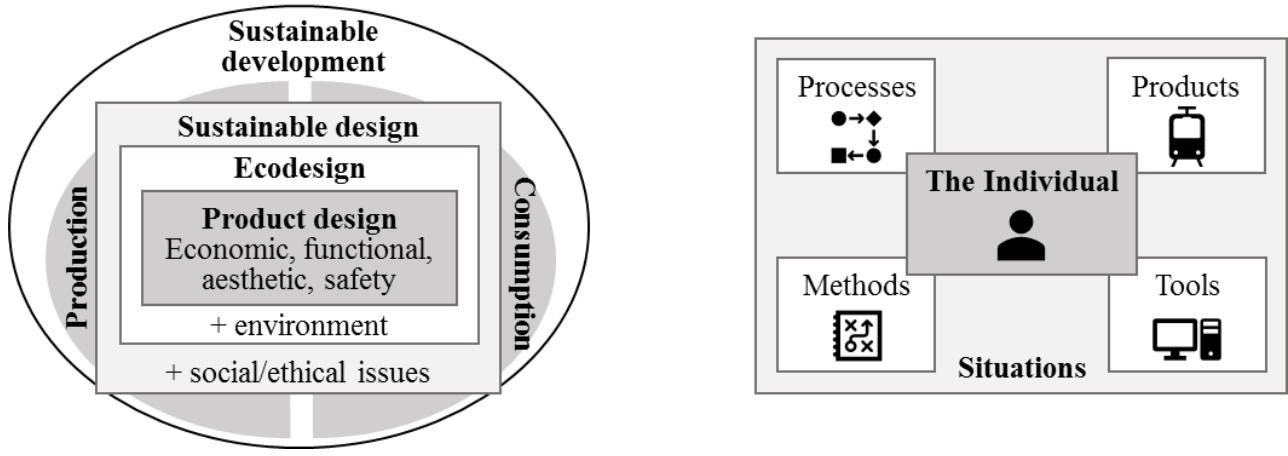

Figure 1. The relationship between product design, Ecodesign and sustainable design (Charter and Tischner, 2001) (left) and the key aspects in product development (Ponn and Lindemann, 2008) (right)

Product development is one of the most important corporate processes and differs from other business processes, as e.g. production, because the related processes are more difficult to anticipate, based on their increased dynamics and variability. To develop successful, which means producible and functional products, processes are necessary, that regulate the procedures of the development and the proceeding of the involved individuals and teams (Ponn and Lindemann, 2008). These development processes are supported by the usage of suitable methods, whose application, in turn, is facilitated by using tools (see Figure 1 on the right side for an overview). Every product development is associated with individual objectives, restrictions and activities that lead to a unique process course (Albers et al., 2012a). Numerous developmental goals and requirements exist that products must meet, which further complicate the development process and its realisation. Thereby depending on the development situation and the product itself, certain key objectives are strived as described in design guidelines such as Design for X. Many of these approaches such as Design for Remanufacturing, Design for Disassembly or Design for Recovery are obviously or implicitly integrated in the concept of Ecodesign (Rossi et al., 2016). But especially in Ecodesign, the entire product and process life cycle including all sub-phases, energy, waste and resource flows in between (Oberender, 2006), as well as the ecologic and economic consequences of changes in one life cycle phase on another have to be considered, when developing or redesigning a product. The fact that the development process will change, when applying Ecodesign, has been confirmed by the growing amount of published methods supporting it (Rossi et al., 2016). However, it is yet unclear how it will change and what that implies for the tasks and activities of the developer and respectively for the required competences.

\subsection{Derivation of competences and competence models}

In the past years, there has been a lively theoretical discourse about the term competence, its modelling, capturing, or rather measuring, in which various scientific disciplines are involved (Jungmann et al., 2016). European and international influences further contribute to the diversification of the terminology. Many terms are used and inconsistently defined to describe educational concepts such as knowledge, skills, abilities and competences. The high variety of the concept of competences results i. a. from the numerous disciplines it is recognised by such as human resources and work process management, strategic management, pedagogic or instructional psychology (Herzog and Bender, 2018). In a pedagogical and instruction psychological context, competences describe the inner prerequisites of a person for self-organized and autonomous acting, thus a person's willingness and ability (Enke et al., 2015). Anderson and Krathwohl (2001), who revised Bloom's well-known taxonomy of educational objectives, define competences (as learning objectives) as a two-dimensional concept consisting of a knowledge dimension (factual, conceptual, procedural and metacognitive) and a cognitive process dimension (remember, understand, apply, analyse, evaluate, create). According to Weinert (2002), different types of competences have to be distinguished, that are needed for different 
tasks, situations and specific fields of action. In the 1970s, Roth (1971) described responsible and mature acting in three forms of competences, self-, social- and subject-specific competence. Mudra (2004) uses the terms personality, social competence as well as professional and methodical competence. Complementing this view, Erpenbeck and Rosenstiel (2011) add a communicative aspect to the social competence and introduce an activity and action-oriented competence group. They developed a widespread and acknowledged competence model with four key competence groups each with diverse sub competencies: personal, activity- and implementation-oriented, professionalmethodical and social-communicative competences (Erpenbeck and Rosenstiel, 2011).

The range of the different competence definitions and the manifold purposes they are used for implies that there are also different concepts and types of competence models, which however exhibit the same core characteristics (Gessler and Sebe-Opfermann, 2016): Competence models summarize competences in general terms or clusters (1), include on a more detailed level respective competences (2), describe on the following levels the psychological characteristics (3) and define observable kinds of behaviour. In summary, competence models are a structured and for an organisation adequately described collection of competences that are important to be able to act successfully within an organisation now (and in the future) (Gessler and Sebe-Opfermann, 2016). General competence models such as the competence atlas (Heyse and Erpenbeck, 2010) or the German qualification framework for lifelong learning (Arbeitskreis Deutscher Qualifikationsrahmen, 2011) "enable a definition of competences for a broad range of professions, they are not appropriate to describe specific competences in a relevant field, due to their generality" (Herzog and Bender, 2018).

The most elaborate and holistic collection of competences in the field of engineering is the CDIO Syllabus. Under the conception that engineers of today are involved in all stages of the product, process and system life cycle, the Massachusetts Institute of Technology (MIT) proposed a list of competences in the form of the CDIO (Conceive, Design, Implement and Operate) that defines what engineering students should know and be able to do to by the end of their studies (Palma et al., 2011). The CDIO's strong practical reference through the involvement of expert interviews combined with the integration of other theoretical models, lead to its high usability and applicability (Crawley, 2001). Nowadays around 120 international universities utilise this competence model to derive their study programs and curricula (Crawley et al., 2011). Within the CDIO, the competences are listed on four levels of hierarchy and grouped into four main categories (1) disciplinary knowledge and reasoning, (2) personal and professional skills and attributes (3) interpersonal skills: teamwork and communication as well as (4) conceiving, designing, implementing and operating systems in the enterprise, societal and environmental context. The categories (2) and (3) resemble the personal and social communicative competence dimensions described by Erpenbeck and Rosenstiel (2011). The specific engineering context of the CDIO syllabus appears in the natural science and engineering knowledge in category (1) and in the work process related competencies in category (4). On the second hierarchy level, there are 19 sub-competences, on the third level 101 competences can be found and on the fourth and most detailed level over 450 competence facets are listed (excerpt in Table 1).

Table 1. Excerpt of the CDIO syllabus on all four levels (Crawley et al., 2011)

\begin{tabular}{|c|c|c|c|c|c|c|c|}
\hline \multicolumn{2}{|c|}{ 1st Level } & \multicolumn{2}{|r|}{ 2nd Level } & \multicolumn{2}{|c|}{ 3rd Level } & \multicolumn{2}{|r|}{ 4th Level } \\
\hline \multirow{8}{*}{2} & \multirow{8}{*}{$\begin{array}{c}\text { PERSONAL } \\
\text { AND } \\
\text { PROFESSIONAL } \\
\text { SKILLS AND } \\
\text { ATTRIBUTES }\end{array}$} & \multirow{8}{*}{2.3} & \multirow{8}{*}{$\begin{array}{c}\text { SYSTEM } \\
\text { THINKING }\end{array}$} & \multirow{4}{*}{2.3 .1} & \multirow{4}{*}{$\begin{array}{l}\text { Thinking } \\
\text { Holistically }\end{array}$} & 2.3.1.1 & A system, its function and behavior, and its elements \\
\hline & & & & & & 2.3.1.2 & $\begin{array}{l}\text { Transdiscipl inary approaches that ensure the system is } \\
\text { understood from all relevant perspectives }\end{array}$ \\
\hline & & & & & & 2.3.1.4 & The societal, enterprise and technical context of the \\
\hline & & & & & & 2.3.1.5 & $\begin{array}{l}\text { The interactions external to the system, and the } \\
\text { behavioral impact of the system }\end{array}$ \\
\hline & & & & \multirow{4}{*}{2.3 .2} & \multirow{4}{*}{$\begin{array}{c}\text { Emergence } \\
\text { and } \\
\text { Interactions in } \\
\text { Systems }\end{array}$} & 2.3.2.1 & $\begin{array}{l}\text { The abstractions necessary to define and model the } \\
\text { entities or elements of the system }\end{array}$ \\
\hline & & & & & & 2.3.2.2 & $\begin{array}{l}\text { The important relationships, interactions and interfaces } \\
\text { among elements }\end{array}$ \\
\hline & & & & & & 2.3.2.3 & $\begin{array}{l}\text { The functional and behavioral properties (intended and } \\
\text { unintended) that emerge from the system }\end{array}$ \\
\hline & & & & & & 2.3.2.5 & Evolutionary adaptation over time \\
\hline
\end{tabular}




\subsection{Description of the competence groups system thinking and communication}

Systems thinking in correlation with sustainability education is defined as "a holistic way of analysing how a system's constituent parts are interrelated and how the system works overtime and within the context of larger systems" (Palmberg et al., 2017). According to the dictionary, communication is an understanding between each other or an interpersonal contact by means of language or signs (Duden, 2019). Within the CDIO Syllabus the competence category "system thinking" includes the following sub-categories thinking holistically, emergence and interactions in systems, prioritization and focus, trade-offs, judgment and balance in resolution (Crawley et al., 2011). While the competence group "communications" encompasses the sub-competences communication strategy, communication structure, written communication, electronic / multimedia communication, graphical communications, oral presentation, inquiry, listening and dialog, negotiation, compromise and conflict resolution, advocacy and establishing diverse connections and networking (Crawley et al., 2011). Each of these sub-categories contains three to eight detailed competences on the fourth level of hierarchy.

\section{Competence analysis for the development of Ecodesign products}

Since Ecodesign has been identified as a promising approach "that can support and strengthen the knowledge, skills and attitude of students in higher education" (Verhulst and van Doorsselaer, 2015), it is of vital importance to examine what specific competences are required to develop environmentally compatible products apart from the technical Ecodesign know-how. The following section begins by describing how the literature research and analysis has been conducted (section 3.1). Afterwards the allocation of the competences is explained (section 3.2) and the results are described (section 3.3). Finally, the sensitivity of the results will be discussed, and limitations of the analysis are pointed out (section 3.4).

\subsection{Material and method}

To identify relevant competences, a vast literature research including monographs, book chapters, dissertations, conference contributions, journal articles and final reports was carried out. Thereby the following terms were used in German and English as well as in varying ways of spelling (e.g. eco-design and Ecodesign): competences, tasks, skills, abilities in relation to product development, design, engineering, integrated product development, product-service systems, Ecodesign, environment, sustainability, university, higher education, engineer, product developer, designer, manager, entrepreneur. Altogether 21 publications were identified that specifically named and addressed necessary competences. The publications could be grouped into the following categories:

1. Focus on product development:

a. Product development in general (Hubka, 1976; Beitz and Helbig, 1997; Albers et al., 2012a; Ernst et al., 2013; Binz, 2014)

b. Integrated design (Riel et al., 2010)

c. Product - Service System development (Modrow-Thiel et al., 2010; Wilkens et al., 2017; Lienert and Schiffer, 2013)

2. Focus on sustainable development:

a. Sustainability in Ecodesign (Lambrechts et al., 2019)

b. Sustainability in higher education (Frisk and Larson, 2011; Rieckmann, 2012; Wiek et al., 2015; Ploum et al., 2018)

c. Sustainability in engineering education (Crofton, 2000)

d. Sustainable entrepreneurship and management (Lans et al., 2014; Wesselink et al., 2015; Ploum et al., 2018; Lambrechts et al., 2019)

3. Focus on Ecodesign:

a. Sustainable product development (O'Rafferty et al., 2014)

b. Environmentally compatible product development (Bennauer, 1994; Ries, 2001) 


\subsection{Procedure for the allocation of competences}

The competences mentioned in the above listed publications had to be segmented and translated in order to be transferred to a competence model from the engineering sector, the CDIO Syllabus (see section 2.2). Each competence was compared to the 60 competence facets of the CDIO on the 4th level of hierarchy within the two competence groups "system thinking" (2.3) and "communications" (3.2). Lienert and Schiffer (2013) for example name "negotiations skills and the ability to handle conflicts" as important competences for the development of product-service systems, as illustrated in Table 2. In this example, the negotiations skills are explicitly named in the CDIO competence facet "3.2.8.2 Negotiation to find acceptable solutions" and thus awarded a full circle (with a value of 2), whereas the ability to handle conflicts is implicitly summarized by the facets "3.2.8.1" and "3.2.8.4." and as a result accessed with a half circle (value of 1).

Table 2. Excerpt of the assessment table of competences for one exemplary publication

\begin{tabular}{|c|c|c|l|c|}
\cline { 3 - 4 } \multicolumn{2}{|c|}{ 3rd Level CDIO } & \multicolumn{2}{|c|}{ 4th Level CDIO } & PSS Development \\
\hline \multirow{3}{*}{3.2 .8} & $\begin{array}{c}\text { Negotiation, } \\
\text { Compromise and } \\
\text { Conflict Resolution }\end{array}$ & 3.2 .8 .1 & Identifying potential disagreements, tensions or conflicts & ( \\
\cline { 3 - 5 } & & 3.2 .8 .2 & Negotiation to find acceptable solutions & \\
\cline { 3 - 5 } & 3.2 .8 .3 & Reaching agreements without compromising fundamental principles & \\
\hline
\end{tabular}

After the detailed assessment of the identified competencies of each publication with the competences list of the CDIO, the results were grouped together according to the above described categories product development, sustainable development and Ecodesign and the percentage distribution was determined.

\subsection{Results of the analysis}

The ten sub-competences on the 4th level of the CDIO with the highest average assessment over all three different content categories are illustrated in Table 3. This overview shows that the competence facet "Engaging and connecting with diverse individuals" is seen as the most important competence for all three categories and thus received the highest overall rank. Altogether, six competence facets belong to the subordinate group communication and the other four to system thinking, thus the distribution of the competences is well-balanced. In summary, rank 1 and 2 (competence no. 59 and 60) can be combined to "Establishing diverse connections and networking - Communication", rank 3,4, 5 and 9 (competence no. $1,2,3,6$ ) belong to the group "Thinking holistically and interconnectedly - System thinking" and the remaining competences with the ranks $6,7,8$ and 10 (competence no. 49, 58,51,50) can be aggregated to "Inquiry, listening, dialog, negotiations and compromise - Communication". In the engineering and product development publications without reference to Ecodesign or sustainability, a significantly higher mention of system thinking competences can be found. In the areas of Product-Service System development, sustainable design and Ecodesign, communicative and collaborative skills are indispensable for successfully developing products. Among other reasons, this is due to the novelty of the product and the accompanying development process, and to the often cross-domain and crossdepartmental development work, which requires a higher degree of communication and cooperation.

These theoretical findings are supported by a practical survey, in which, the participants (a total of eight experts) of a project meeting for the research project "EcoING", were asked to determine the most important competences for the development of Ecodesign products on the basis of the competences listed in the CDIO syllabus for the groups system thinking and communication. With the result that both rankings appear very similar and all theoretically identified top ten competences were named at least once by one of the practical experts.

Initial studies examining the learning goals and content of existing international Ecodesign and sustainability courses from the Technical University of Denmark (DTU), the Technical University of Vienna and the University of Antwerp as well as national courses form the Frankfurt University of Applied Sciences and the Esslingen University of Applied Sciences show that system thinking is strongly addressed only in the course "Sustainability in engineering solution" at DTU (Olsen et al., 
2015) and communicative learning goals are incorporated merely in the course "Ecological design" at Esslingen University of Applied Sciences. (Hochschule Esslingen, 2017).

Table 3. The ten CDIO competence on the 4th level with the highest average assessment

\begin{tabular}{|c|c|c|c|c|c|c|c|c|c|}
\hline \multirow[b]{2}{*}{ No. } & \multirow[b]{2}{*}{$\begin{array}{l}\text { Comp. } \\
\text { group }\end{array}$} & \multirow[b]{2}{*}{ Competence (CDIO) on the 4th level } & \multicolumn{2}{|c|}{$\begin{array}{c}\text { Product } \\
\text { development }\end{array}$} & \multicolumn{2}{|c|}{$\begin{array}{c}\text { Sustainable } \\
\text { development }\end{array}$} & \multicolumn{2}{|c|}{ Ecodesign } & \multirow{2}{*}{ Average } \\
\hline & & & $\begin{array}{l}\text { No. of } \\
\text { mentions }\end{array}$ & $\begin{array}{c}\text { Per- } \\
\text { centage }\end{array}$ & $\begin{array}{c}\text { No.of } \\
\text { mentions }\end{array}$ & $\begin{array}{c}\text { Per- } \\
\text { centage }\end{array}$ & $\begin{array}{l}\text { No. of } \\
\text { mentions }\end{array}$ & $\begin{array}{c}\text { Per- } \\
\text { centage }\end{array}$ & \\
\hline 59 & $\mathrm{C}$ & $\begin{array}{l}\text { Engaging and connecting with diverse } \\
\text { individuals }\end{array}$ & 14 & $11 \%$ & 14 & $10 \%$ & 6 & $14 \%$ & $11,3 \%$ \\
\hline 60 & $\mathrm{C}$ & Activating and using networks to achieve goals & 8 & $6 \%$ & 4 & $3 \%$ & 5 & $11 \%$ & $6,7 \%$ \\
\hline 1 & $S$ & $\begin{array}{l}\text { A system, its function and behaviour, and its } \\
\text { elements }\end{array}$ & 8 & $6 \%$ & 11 & $8 \%$ & 2 & $5 \%$ & $6,1 \%$ \\
\hline 2 & $S$ & $\begin{array}{l}\text { Transdisciplinary approaches that ensure the } \\
\text { system is understood from all relevant } \\
\text { perspectives }\end{array}$ & 5 & $4 \%$ & 13 & $9 \%$ & 2 & $5 \%$ & $5,8 \%$ \\
\hline 49 & $\mathrm{C}$ & $\begin{array}{l}\text { Recognizing ideas that may be better than your } \\
\text { own }\end{array}$ & 4 & $3 \%$ & 7 & $5 \%$ & 3 & $7 \%$ & $4,9 \%$ \\
\hline 3 & $S$ & $\begin{array}{l}\text { The societal, enterprise and technical context } \\
\text { of the system }\end{array}$ & 2 & $2 \%$ & 12 & $8 \%$ & 2 & $5 \%$ & $4,8 \%$ \\
\hline 58 & $\mathrm{C}$ & $\begin{array}{l}\text { Appreciating those with different skills, cultures } \\
\text { or experiences }\end{array}$ & 3 & $2 \%$ & 10 & $7 \%$ & 2 & $5 \%$ & $4,6 \%$ \\
\hline 51 & $\mathrm{C}$ & Negotiation to find acceptable solutions & 7 & $5 \%$ & 4 & $3 \%$ & 1 & $2 \%$ & $3,4 \%$ \\
\hline 6 & $S$ & $\begin{array}{l}\text { The important relationships, interactions and } \\
\text { interfaces among elements }\end{array}$ & 0 & $0 \%$ & 8 & $6 \%$ & 2 & $5 \%$ & $3,4 \%$ \\
\hline 50 & $\mathrm{C}$ & $\begin{array}{l}\text { Identifying potential disagreements, tensions or } \\
\text { conflicts }\end{array}$ & 3 & $2 \%$ & 1 & $1 \%$ & 3 & $7 \%$ & $3,3 \%$ \\
\hline
\end{tabular}

\subsection{Sensitivity analysis}

In order to test the sensitivity or rather stability of the conducted competence analysis, the input data has been varied. For this purpose, three sets of criteria to either increase or decrease the significance of each publication could be derived (see Table 4). These sets were identified as the major differentiating factors, when comparing the different publications at hand. Based on the degree of fulfilment as used in other methods, such as the assessment of technical systems (Breiing and Knosala, 1997), the valuation of each attribute varies between $2 / 3,1$ and $3 / 2$. For each publication its average valuation is calculated and then used to multiply the values of each competence facet of the CDIO as shown in Table 2.

Table 4. Overview of the different attributes and valuations of the sensitivity analysis and an exemplary valuation

\begin{tabular}{|c|c|c|c|}
\hline & & & $\begin{array}{l}\text { Environmentally compatible } \\
\text { product development }\end{array}$ \\
\hline Property & Attributes & Valuation & Bennauer (1994) \\
\hline \multirow{3}{*}{ Acuality } & Less than ten years (up tp 2010) & $3 / 2$ & \multirow{3}{*}{$2 / 3$} \\
\hline & Less than twenty years (up to 2000) & 1 & \\
\hline & More than twenty years (2009 and older) & $2 / 3$ & \\
\hline \multirow{3}{*}{$\begin{array}{l}\text { Relation to Product } \\
\text { Development }\end{array}$} & Classic product development & $3 / 2$ & \multirow{3}{*}{$3 / 2$} \\
\hline & Engineering & 1 & \\
\hline & Nontechnical context & $2 / 3$ & \\
\hline \multirow{3}{*}{$\begin{array}{l}\text { Relation to } \\
\text { Ecodesign }\end{array}$} & Environmentally compatible and socia//ethical & $3 / 2$ & \multirow{3}{*}{$3 / 2$} \\
\hline & Environmentally compatible & 1 & \\
\hline & Nonenvironmental context & $2 / 3$ & \\
\hline \multicolumn{3}{|c|}{ Average valuation } & 1,1223 \\
\hline
\end{tabular}


Consequently, publications with a high topicality and a strong relation to product development and Ecodesign have a much higher impact on the overall results as for example an older publication that does not have a technical or environmental context. After changing the input data, the ranking of the top ten competence facets as shown in Table 3 did not change, only the individual numbers of mentions or the percentages changed minimally. The greatest variation on the average percentage of the sum of competences was $0.2 \%$ and the average deviation amounts to $0,08 \%$. Therefore, the results can be regarded as stable and resilient.

\subsection{Limitations of the analysis}

Even though the authors objectively assessed the identified competences with the competence facets of the CDIO Syllabus, an even higher degree of objectivity could be reached by increasing the number of participating researchers. The hypothesis that the instilled teaching content in higher education institutions eventually leads to an increased implementation of those topics in industry is taken as a basis for this analysis. The transfer problems of design methodologies from research into the industry are not part of this research.

\section{Conclusions}

So far there has been no publication, which compared and analysed the competences needed for product development, sustainable development and Ecodesign with a widespread competence model such as the CDIO Syllabus. This publication presents a conceptual and analytical approach to derive required competences for the development of Ecodesign products beyond domain specific know-how (such as life cycle assessment). The results show that especially communicative abilities when working together with other individuals as well as system specific knowledge about the system itself and its functions from different perspectives are of great importance for the development of Ecodesign products. As next step of research, the identified competence facets have to be elaborated in the context of specific development situations (concerning for example the type of product or the organisation of the company). With that different tasks and skills can be further detailed that are needed to be able to implement Ecodesign successfully in product development projects. Within the project "EcoING", the educational goals and learning outcomes will be conceived next based on the competences identified within this publication as well as on the accompanying technical Ecodesign expertise and know-how.

\section{Acknowledgements}

This research and the project "EcoING" are funded by the German federal foundation of environment (Deutsche Bundesstiftung Umwelt - DBU).

\section{References}

Albers, A., Burkardt, N. and Becke, C. (2012a), "KaLeP: Karlsruher Lehrmodell für Produktentwicklung. Ein Ansatz zur Kompetenzerfassung in der Ingenieurausbildung”, In: Pfadenhauer, M. and Kunz, A.M. (Eds.), Kompetenzen in der Kompetenzerfassung: Ansätze und Auswirkungen der Vermessung von Bildung, Beltz Juventa, Weinheim, pp. 75-86.

Albers, A., Denkena, B. and Matthiesen, S. (2012b), Faszination Konstruktion: Berufsbild und Tätigkeitsfeld im Wandel, arcatech STUDIE.

Anderson, L.W. and Krathwohl, D.R. (2001), A taxonomy for learning, teaching, and assessing: A revision of Bloom's taxonomy of educational objectives, Abridged ed., [Nachdr.], Longman, New York.

Arbeitskreis Deutscher Qualifikationsrahmen (AK DQR) (2011), Deutscher Qualifikationsrahmen für lebenslanges Lernen, (accessed 11 June 2019).

Beitz, W. and Helbig, D. (1997), Neue Wege zur Produktentwicklung: Berufsfähigkeit und Weiterbildung, [Abschlußbericht des Arbeitskreises, Schriftenreihe Konstruktionstechnik], Vol. 37, TU Univ.-Bibliothek Abt. Publ, Berlin.

Bennauer, U. (1994), Ökologieorientierte Produktentwicklung: Eine strategisch-technologische Betrachtung der betriebswirtschaftlichen Rahmenbedingungen, Umwelt und Ökonomie, Vol. 9, Physica-Verlag HD, Heidelberg.

Binz, H. (2014), "Universitäre Lehre in der Produktentwicklung. Leitfaden der Wissenschaftlichen Gesellschaft für Produktentwicklung”, Konstruktion, No. 6, pp. 74-79. 
Blessing, L.T.M. and Chakrabarti, A. (2009), DRM, a design research methodology, Springer, Dordrecht, New York.

Breiing, A. and Knosala, R. (1997), Bewerten technischer Systeme: Theoretische und methodische Grundlagen bewertungstechnischer Entscheidungshilfen, Springer, Berlin.

Charter, M. and Tischner, U. (2001), Sustainable solutions: Developing products and services for the future, Greenleaf Pub., Sheffield, U.K.

Crawley, E.F. (2001), The CDIO Syllabus: A Statement of Goals for Undergraduate Engineering Education.

Crawley, E.F. et al. (2011), "The CDIO Syllabus v2.0. An Updated Statement of Goals for Engineering Education", Proceedings of the 7th International CDIO Conference, Technical University of Denmark, Copenhagen, June 20-23.

Crofton, F.S. (2000), "Educating for sustainability: opportunities in undergraduate engineering", Journal of Cleaner Production, Vol. 8 No. 5, pp. 397-405. https://doi.org/10.1016/S0959-6526(00)00043-3

DIN (2011), Umweltmanagementsysteme - Leitlinien zur Berücksichtigung umweltverträglicher Produktgestaltung, Vol. 13.020.10 No. DIN EN ISO 14006:2011-10.

Duden (2019), Kommunikation, available at: https://www.duden.de/rechtschreibung/Kommunikation (accessed 11 November 2019).

Enke, J., Kraft, K. and Metternich, J. (2015), "Competency-oriented Design of Learning Modules", paper presented at Conference on Learning Factories, pp. 7-8, Juli, Bochum (accessed 28 July 2015) https://doi.org/10.1016/j.procir.2015.02.211

Ernst, J. et al. (2013), Humanfaktoren in der Produktentwicklung: Kurzbericht, Kaiserslautern.

Erpenbeck, J. and Rosenstiel, L.V. (2011), Handbuch Kompetenzmessung: Erkennen, verstehen und bewerten von Kompetenzen in der betrieblichen, pädagogischen und psychologischen Praxis, 2nd ed, SchäfferPoeschel Verlag für Wirtschaft Steuern Recht, Stuttgart.

Frisk, E. and Larson, K.L. (2011), "Educating for Sustainability: Competencies \& Practices for Transformative Action”, Journal of Sustainability Education, Vol. 2

Gessler, M. and Sebe-Opfermann, A. (2016), "Kompetenzmodelle”, In: Müller-Vorbrüggen, M. and Radel, J. (Eds.), Handbuch Personalentwicklung: Die Praxis der Personalbildung, Personalförderung und Arbeitsstrukturierung, 4., überarbeitete und erweiterte Auflage, Schäffer Poeschel, Stuttgart.

Graulich, K. et al. (2017), "Ökologisches Design als Qualitätskriterium in Unternehmen stärken. Endbericht”, Umweltbundesamt, No. 35.

Herzog, M. and Bender, B. (2018), "Competencies for the development of smart products”, In: Maier, A., Kim, H., Oehmen, J., Salustri, F., Škec, S. and Kokkolaras, M. (Eds.), Design education, Curran Associates Inc, Red Hook, NY, pp. 285-294.

Heyse, V. and Erpenbeck, J. (2010), Kompetenztraining: Informations- und Trainingsprogramme, 2., überarb. u. erw. Aufl, Schäffer-Poeschel, Stuttgart.

Esslingen, H. (2017), Modulhandbuch: Masterstudiengang Ressourceneffizienz im Maschinenbau, available at: http://www.hs-esslingen.de/fileadmin/medien/fakultaeten/mb/Modulhandbuch_RMM_2017.05.pdf (accessed 22 November 2017).

Hubka, V. (1976), Theorie der Konstruktionsprozesse: Analyse der Konstruktionstätigkeit, Hochschultext, Springer, Berlin, Heidelberg.

Johansson, G. (2002), "Success factors for integration of ecodesign in product development", Environmental Management and Health, Vol. 13 No. 1, pp. 98-107. https://doi.org/10.1108/09566160210417868

Jungmann, T., Ossenberg, P. and Wissemann, S. (2016), "Begriffsklärung zur Kompetenzorientierung”, In: Frerich, S., Meisen, T., Richert, A., Petermann, M., Jeschke, S., Wilkesmann, U. and Tekkaya, A.E. (Eds.), Engineering Education 4.0, Springer International Publishing, Cham, pp. 863-868. https://doi.org/10.1007/978-3-319-469164_70

Kattwinkel, D., Song, Y.-W. and Bender, B. (2018), “Analysis of Ecodesign and Sustainable Design in Higher Education", In Proceedings of the DESIGN 2018, 15th International Design Conference: 15th International Design Conference (DESIGN 2018), Dubrovnik, pp. 2451-2460. https://doi.org/10.21278/idc.2018.0305

Lambrechts, W. et al. (2019), "The role of individual sustainability competences in eco-design building projects", Journal of Cleaner Production, Vol. 208, pp. 1631-1641. https://doi.org/10.1016/j.jclepro.2018.10.084

Lans, T., Blok, V. and Wesselink, R. (2014), "Learning apart and together: towards an integrated competence framework for sustainable entrepreneurship in higher education", Journal of Cleaner Production, Vol. 62, pp. 37-47. https://doi.org/10.1016/j.jclepro.2013.03.036

Lienert, A.M. and Schiffer, B. (2013), "Where to gain future competencies for Industrial Product-Service Systems (IPS2)?”, 41st SEFI Conference 16-20 September 2013, Leuven, Belgium.

Modrow-Thiel, B. et al. (2010), “Arbeitsintegrierter Kompetenzaufbau”, In: Aurich, J.C. and Clement, M.H. (Eds.), Produkt-Service Systeme, Vol. 1, Springer Berlin Heidelberg, Berlin, Heidelberg, pp. 117-162. https://doi.org/10.1007/978-3-642-01407-9_7 
Mudra, P. (2004), Personalentwicklung: Integrative Gestaltung betrieblicher Lern- und Veränderungsprozesse, Vahlen, München.

Oberender, C. (2006), Die Nutzungsphase und ihre Bedeutung für die Entwicklung umweltgerechter Produkte, Fortschritt-Berichte VDI, Reihe 1, Konstruktionstechnik/Maschinenelemente, nr. 385, VDI Verlag, Düsseldorf.

Olsen, S.I. et al. (2015), "Teaching sustainable solutions in engineering", In IJISD, Vol. 9 No. 2, p. 157. https://doi.org/10.1504/IJISD.2015.068788

O'Rafferty, S., Curtis, H. and O'Connor, F. (2014), "Mainstreaming sustainability in design education - a capacity building framework", International Journal of Sustainability in Higher Education, Vol. 15 No. 2, pp. 169-187. https://doi.org/10.1108/IJSHE-05-2012-0044

Palma, M., Ríos, I.d.l. and Miñán, E. (2011), "Generic competences in engineering field: a comparative study between Latin America and European Union”, Procedia - Social and Behavioral Sciences, Vol. 15, pp. 576585. https://doi.org/10.1016/j.sbspro.2011.03.144

Palmberg, I. et al. (2017), "Systems Thinking for Understanding Sustainability? Nordic Student Teachers' Views on the Relationship between Species Identification, Biodiversity and Sustainable Development", Education Sciences, Vol. 7 No. 3, p. 72. https://doi.org/10.3390/educsci7030072

Ploum, L. et al. (2018), "Toward a Validated Competence Framework for Sustainable Entrepreneurship", Organization \& environment, Vol. 31 No. 2, pp. 113-132. https://doi.org/10.1177/1086026617697039

Ponn, J. and Lindemann, U. (2008), Konzeptentwicklung und Gestaltung technischer Produkte, Springer, Berlin Heidelberg, Berlin, Heidelberg.

Preißler, I. et al. (2010), “Hochschuldidaktik trifft Ingenieursausbildung: Segen oder Fluch?”, Didaktik der Physik.

Rieckmann, M. (2012), "Future-oriented higher education: Which key competencies should be fostered through university teaching and learning?", Futures, Vol. 44 No. 2, pp. 127-135. https://doi.org/10.1016/j.futures. 2011.09.005

Riel, A., Tichkiewitch, S. and Messnarz, R. (2010), "Qualification and certification for the competitive edge in Integrated Design”, CIRP Journal of Manufacturing Science and Technology, Vol. 2 No. 4, pp. 279-289. https://doi.org/10.1016/j.cirpj.2010.04.005

Ries, G. (2001), Umweltkompetenzen und Wissensmanagement für eine proaktive Produktentwicklung: Konzepte und Fallstudie in einem Grossunternehmen im Bausektor, Wirtschaft, Energie, Umwelt, Vdf, Hochsch.-Verl. an der ETH [u.a.], Zürich [u.a.].

Rossi, M., Germani, M. and Zamagni, A. (2016), "Review of ecodesign methods and tools. Barriers and strategies for an effective implementation in industrial companies", Journal of Cleaner Production, Vol. 129, pp. 361-373. https://doi.org/10.1016/j.jclepro.2016.04.051

Roth, H. (1971), "Pädagogische Anthropologie", In: Roth, H. (Ed.), Entwicklung und Erziehung: Grundlagen einer Entwicklungspädagogik, Vol. 2, 1st ed., Hannover.

Verhulst, E. and van Doorsselaer, K. (2015), "Development of a hands-on toolkit to support integration of ecodesign in engineering programmes", Journal of Cleaner Production, Vol. 108, pp. 772-783. https://doi.org/10.1016/j.jclepro.2015.06.083

Weinert, F.E. (2002), Leistungsmessungen in Schulen, Beltz Pädagogik, 2., unveränd, Aufl., Dr. nach Typoskript, Beltz, Weinheim.

Wesselink, R. et al. (2015), "Individual competencies for managers engaged in corporate sustainable management practices", Journal of Cleaner Production, Vol. 106, pp. 497-506. https://doi.org/10.1016/ j.jclepro.2014.10.093

Wiek, A. et al. (2015), "Operationalising competencies in higher education for sustainable development", In: Barth, M., Michelsen, G., Rieckmann, M. and Thomas, I. (Eds.), Handbook of Higher Education for Sustainable Development, Routledge, London, pp. 241-260.

Wiek, A., Withycombe, L. and Redman, C.L. (2011), "Key competencies in sustainability: a reference framework for academic program development", Sustainability Science, Vol. 6 No. 2, pp. 203-218. https://doi.org/10.1007/s11625-011-0132-6

Wilkens, U. et al. (2017), "Personal, Führung und Organisation in IPSS", In: Meier, H. and Uhlmann, E. (Eds.), Industrielle Produkt-Service Systeme, Vol. 20, Springer Berlin Heidelberg, Berlin, Heidelberg, pp. 325-342. https://doi.org/10.1007/978-3-662-48018-2_14 